\title{
Foreign Reserve Management and Economic Growth in Nigeria, 1990-2018
}

\author{
Egbulonu, Kelechukwu Godslove* Okani, Bethel-Bernards C. \\ Department of Economics, Imo State University, PMB 2000, Owerri, Imo State, Nigeria
}

\begin{abstract}
The management, administration and utilization of Foreign External Reserves- foreign currency deposits of the apex bank (Central Banks) or other monetary or financial institutions has been a major macroeconomic challenge especially for developing economies like Nigeria. Over the past three decades, Nigeria has witnessed fluctuations in its reserve accumulation and taken numerous policy measures in the management of its external reserves. This study investigated the impact of foreign reserve accumulation and the country's reserve management policies on its economic growth for the period 1990 to 2018. Secondary data from the United Nations Center for Trade and Development (UNCTAD), World Bank, IMF and Index Mundi Statistical Bulletin were used in the study. The data were subjected to unit root test, cointegration test and Granger Causality tests, The tests revealed that all the variables were integrated at I(1) and are cointegrated. The ECM result showed a long run relationship among the variables in our model. The OLS regression result shows an inverse and insignificant relationship between reserve accumulation and the country's economic growth. The Reserve to GDP ratio of the country is found to be so low and significantly inversely related to the GDP per capita. Other variables in our model- MPR, BOP, FDI and Foreign Remittances were all found to have positive relationship with the MPR and Exchange rate found to be insignificant. The Granger Causality test shows that exchange rate ad foreign remittances are the dominant variables in our model. The study recommends a holistic reappraisal of the country's exchange reserve policy, a judicious and sustainable use of foreign reserve and need to strengthen the domestic capital market.
\end{abstract}

Keywords: Balance of Payment, Foreign Reserve Management, Foreign Remittances, Granger Causality.

DOI: $10.7176 / \mathrm{JESD} / 10-18-16$

Publication date:September $30^{\text {th }} 2019$

\section{Introduction}

Foreign reserves often referred to as international reserves, external reserves or foreign exchange reserves. While there may be many definitions of foreign reserves, CBN (2017) reaffirms the International Monetary Fund (IMF) proposed definition in its BOP Manual, $5^{\text {th }}$ edition as the most widely accepted definition. It defined Foreign Reserve as 'consisting of official public sector foreign assets that are readily available to, and controlled by the monetary authorities, for direct financing of payments of imbalances, and directly regulating the magnitude of such imbalances through intervention in the exchange markets to affect the currency exchange rate and/or for other purposes'

In recent years, the Nigerian economy has witnessed massive shocks ranging from recession, downturn in Foreign Direct Investment (FDI) and other macroeconomic growth indicators. Inflation rate has risen to towering levels over the years- 15.72 percent in 2016, a 57 percent rise from the previous year and reaching a peak of 16.5 percent in 2017. The economy has witnessed an exchange rate instability standing at N360 per dollar in 2017 and has remained unstable over time. Direct Foreign Investment has gone so low and the economy has witnessed severe panic. The $\mathrm{CBN}$ in its fiscal policy measure publication in 2012 maintains that the evolution of the foreign exchange market in Nigeria is influenced by a number of factors such as changing pattern of international trade, institutional changes in the economy and structural shifts in production

Fukuda and Kon (2010) observed that the recent accumulation in foreign exchange reserves has reached record-breaking levels in many developing countries, raising both liquid and total debt while shortening debt maturity. They further argue that foreign reserve accumulation improves investment and economic growth when the tradable sector is capital intensive.

The question of whether foreign exchange accumulation impacts economic growth positively or is a mere buffer against economic crisis is what this paper intends to investigate. Also, we intend to investigate the Nigerian foreign reserve management policy. This is because foreign reserve management has been an important macroeconomic challenge and a decision regarding Reserve Management Objectives (RMO) in other to promote economic growth through capital investment is a crucial one. Also, the Nigerian situation, like many other developing countries has had the challenge of defining what a "desirable" volume of reserve should be. Different schools of thought have been divided on the issue with a school of thought believing that funds stored away in foreign reserves does not reflect positively on capital investment in Nigeria.

\subsection{Statement of the Problem}

The management, administration and utilization of Foreign External Reserves- foreign currency deposits of the 
apex bank (Central Banks) or other monetary or financial institutions has been a major macroeconomic challenge especially for developing economies like Nigeria. Over the past three decades, Nigeria has taken numerous policy initiatives and measures in the management of its external reserves with the latest being the introduction in 2006 of Whole Sales Dutch Auction System (WDAS) which is aimed at the liberalization of the foreign exchange market. However, very little has been achieved in terms of achieving sustainable exchange rate of the naira, favourable terms of trade and economic growth. The structure in place does not support efficient reserve management. Worst still, Nigeria economy, since 1970 has persistently depended on crude oil export as its main foreign exchange earner, accounting for more than $90 \%$ of foreign earning with the attendant circles of economic booms and bursts

From 1999 until the shale oil revolution of the last decade, oil prices began to rise steadily leading to unprecedented accumulation in the country's external reserve- from US\$4.98billion in 1999 to US\$59.37billion in 2007; reaching an all time high of US\$62.081billion in 2008. The shale revolution with production crisis in the Niger Delta region led to a massive fall in the international oil price to an average of US $\$ 45.01$ per barrel between 2015 and 2017 causing a depletion in the country's foreign reserve and consequently, lunching the country into recession.

Akinwumi (2016) observed that between 1999 and 2015, the economy has witnessed all kinds of shock. For the period 2000-2005 the policy attention of the government has been turned to offsetting huge foreign debts owed the Paris club, The International Monetary Fund (IMF) and other International development partners. The federal government within that period of time entered into series of negotiations with the International Development Partners that was awarded with a cancellation of its foreign debt profile.

However, by 2008, the gain of the debt cancellation was eroded by a slump in the terms of trade. The balance of payment worsened - virtually everything in the country was imported. So the government policies were concentrated on efforts to improve the balance of trade deficit of the country. By 2011, the economy started experiencing a slight improvement in the indices of economic growth.

The economic situation of the country calls for urgent macroeconomic attention- it was obvious that the monetary authorities have failed to implement a well structured strategy in the management and administration of the country's monetary policies.

The monetary policy administrators, rather, have turned their effort to strengthening the country's Foreign External Reserve. Akinwumi et al (2016) argued that Nigerian economic crisis over the years result from "the inability of the monetary authorities to proffer well structured strategies in the country's external reserve". That a strong Foreign Reserve is a buffer in times of economic crisis and will be a safeguard against volatility of exchange rate of the domestic currency is an established fact. However, whether such increase will translate to or encourage sustainable economic growth or mere buffer for adverse economic situations is what this paper is intended to investigate.

\subsection{Objectives of the Study}

In view of the debate about the effect of a well coordinated and administered Foreign External Reserve on the economic development of a developing economy like Nigeria, this paper investigates the following:

1. The relationship between foreign external reserve and the exchange rate of the local currency and Foreign Direct Investment (FDI) in Nigeria.

2. The effect of Foreign External Reserve on economic growth of Nigeria.

3. The foreign external reserve policies of Nigeria in terms of its administration, management and utilization in relation to the broad macroeconomic monetary policies of the Federal monetary authorities.

\section{Literature Review}

\subsection{Meaning of Foreign Reserve Management}

IMF (2009) defines Foreign Reserve as 'consisting of official public sector foreign assets that are readily available to, and controlled by the monetary authorities, for direct financing of payments of imbalances, and directly regulating the magnitude of such imbalances through intervention in the exchange markets to affect the currency exchange rate and/or for other purposes' It includes foreign currency deposits of Central Banks or other monetary authorities used to back Central Bank's liabilities such as the local currency issued, the reserve deposits of various Deposit Money Banks (DMBs), government or other financial institutions. This means that foreign exchange holdings of individuals, banks, government agencies and corporate bodies do not form part of the nation's Foreign External Reserves. Even though the management of the country's foreign exchange stability is one of the main reasons why many countries - especially developing countries like Nigeria emphasize on maintaining desirable volume of external reserve, one of the biggest challenges faced domestically is what level of foreign reserve that should be considered adequate or desirable.

\subsubsection{The Challenges of an Optimal Level of External Reserve}

The argument about what should be reserved has been a point of controversy between the component units that make up the Nigerian federal structure and most times have rallied on the courts to make such critical 
macroeconomic decision.

Furthermore, there has been division among development economists on what a desirable and adequate level of reserve by a developing economy should be. One school of thought holds that an "adequate" foreign exchange reserve is one that is just enough to maintain balance of payment equilibrium for a developing economy so that resources should be rightly invested in infrastructure, human and capital development as well as research. It maintains that external reserves are just foreign savings which should serve as a buffer when the economy is facing severe crisis and holds the opinion that if the monetary authorities should intervene but minimally so that the market forces maintains a balance in the foreign exchange market without undue interference, there will always be an equilibrium between the demand for and supply of a country's local currency, hence diverting development funds to another foreign economy won't be necessary. However, the second school of thought argues that foreign exchange stability cannot be maintained with a depleted external reserve in case of economic shocks.

Akinwumi et al (2016) observed that external reserves is essential to the economy of Nigeria and must be kept at a "desirable" level so as to achieve its purpose and went ahead to establish a positive relationship with Foreign Direct Investment, economic growth and monetary policy rate and negative relationship between External Reserve and inflation and exchange rate. They further observed that sound reserve management policies and practices can support but not substitute for sound macroeconomic management.

Inappropriate economic policies can pose serious risk to the ability to manage reserves. IMF (2003) stipulates that reserve management should ensure that adequate official public sector foreign assets are readily available to and controlled by the authorities for meeting defined range of objectives for the country. The central bank is the statutory macroeconomic authority charged with the administration and management of the Nigerian foreign external reserve.

Fakunda and Kon (2010) also observed that an increase in foreign exchange reserve raises both liquidity and total debt with shortening debt maturity to the extent that foreign exchange reserve interest rates are low, increased foreign reserve will cause a decline in aggregate consumption as well as move labour from the non-tradable to the tradable sector. However, if the tradable sector is capital intensive, increased foreign external reserve may enhance investment and economic growth.

2.1.2 Rationale For Holding Reserves

Some of the reasons why countries hold external reserves according to CBN (2006) are;

1. To safeguard the value of domestic currency.

2. For timely meeting of international payment obligations as the need to finance international trade give rise to demand for liquid reserve.

3. As a store of value to accumulate excess wealth for future consumption purposes, especially in the developing countries.

4. To manage the exchange rate and enable an orderly absorption of international money and capital flows.

5. To boost the country's credit worthiness.

6. To provide a fall back for the rainy day', and

7. To provide a buffer against external shocks.

2.1.3 Composition of Nigeria's Foreign Reserve

The CBN Act 1991 vests the custody and management of the country's external reserve on the Central Bank of Nigeria and listed the following as the composition of Nigeria's foreign reserve.

1) Gold coin or bullion

2) Balance at any bank outside Nigeria where the currency is freely convertible.

3) Treasury bills having a maturity not exceeding one year issued by the government of any country outside Nigeria whose currency is freely convertible and the securities shall mature in a period not exceeding 10 years from the date of acquisition.

4) Securities of or guarantees by international financial institutions

5) Nigeria's gold tranche at the IMF

6) Allocations of special drawing rights made to Nigeria by the IMF.

\subsubsection{Components of the Nigeria External Reserve}

The Foreign Operations Department of the CBN is saddled with the responsibility of overseeing the structure of Nigeria foreign reserve which comprises of three components namely- the federations, the federal government and the CBN portions. The federation component consist of sterilized funds (unmonetized) held in the excess crude and PPT Royalty at the CBN belonging to the three tiers of government. The federal government component refers to the fund belonging to some federal government agencies such as NNPC (for financing its joint venture expenses), PHCN AND Ministry of defense (for letters of credit opened on their behalf) etc. The CBN component consists of funds that have been monetized and shared. This arises as the bank receives foreign exchange inflows from crude oil sales and other oil revenues on behalf of the federation. Such proceeds are purchased by the bank and the naira equivalent credited to the federation account. The monetized foreign exchange, thus, belongs to the Central Bank from where it conducts its monetary policies and defends the value of the naira. 


\subsubsection{Challenges of Managing Nigeria's External Reserve}

What is the end point of foreign reserve accumulation? Does a fat foreign reserve indicate economic prosperity for a country or a means to guarantee sustainable growth? Soludo (2005) recommends that in management of the country's external reserve, the following questions should be addressed:

1. How much that would be spent or saved at any given time..

2. What is the reserve being spent on?

3. How do you ensure transparency and accountability in managing consumption and savings?

4. What is the level of volatility of the foreign exchange inflows?

\subsection{Theoretical Literature}

2.2.1 Theory of Self-Insurance: Fakuda and Kon (2008) popularized the self-insurance theory which explains the holding of buffer stock of reserve to deal with the unforeseen shocks in the international financial markets. Guillermo (2009) argued that reserve accumulation and easy money helped caused the Subprime Crisis. His argument on the counter productivity of reserve accumulation gained widespread popularity in the US and Europe as one of the fundamental explanations for recurrent economic crisis in the emerging markets. Guillermo gave the following reasons as the main factors that led to self-insurance policies

$>$ A starting point is the 1997/98 Asian/Russian crisis which showed emerging economies the advantage of holding a large stock of international reserve to protect their domestic financial system without IMF cooperation. This self-insurance motive is supported by recent empirical research; though recently the selfinsurance motive for resource accumulation appears to be triggered by other factors.

$>$ Assuming that reserve money is a composite of currency and treasury bills, let $\mathrm{s}$ be the nominal interest rate on reserve money. Thus when the demand for international reserve goes up, the federal government can opt for accommodating its supply or lowering the policy interest rate.

In summary, the increase in the demand for international reserve accompanied by low interest rates and lax financial regulations may lead to a large scale creation of quasi money subject to self-fulfilling expectations which may run the economy into liquidity collapse, setting in motion strong price deflation forces (Guillermo, 2009).

2.2.2 International Financial Integration Theory: the international financial integration theory, according to Nwafor (2017), advocates that international integration should cause capital to flow from high income countries characterized by high capital -labour ratios to low income countries with lower capital-labour ratios. Prasad and Rajam (2008) noted that this approach would improve the level of investment through the access to foreign capital and boost growth in the poor country and support higher returns to foreign investors who would be induced to make capital flow abroad. This process of capital flow liberalization would stimulate foreign exchange stability and favourable terms of trade.

2.2.3 Lender of Last Resort (LOLR) Theory: Guillermo (2009) in response to the US Subprime crisis popularized the lender of last resort theory. A massive failure of the shadow banking system that crumbled the domestic capital market, triggering global wide deleveraging was put forward by the theory as the major cause of the crisis. A resultant distance between savers and private sector investors leads to fall in aggregate demand and a search for safe assets. With the virtual disappearance of investment banks, only fiscal stimulus packages are second best in restoring liquidity in the private sector and consequently increase capacity utilization. Guillermo argued that rapid effects are unlikely because output is credit-constrained and reserve accumulation is time consuming, credit availability to cushion shocks can be counterproductive unless it is accompanied by the establishment of a Lender of Last Resort (LOLR) that radically softens the severity of financial crisis by providing timely credit loans.

2.2.4 The Mercantile Theory of Reserve Accumulation: Gupta and Agarwal (2004) and Aizenman and Lee (2008) explained the mercantile motive of reserve accumulation. This theory holds that expansion of trade and other interactions in the financial system necessitates the increase in accumulation of external reserves especially where the domestic economy has a history of volatility and fluctuations. Choi and Taylor (2018) made a distinction between the mercantilist motive and the precautionary motives of reserve accumulation thus;

"If an economy is more vulnerable to crisis, the government will want to accumulate more precautionary savings in the form of reserves. At the same time the private sector will want to expand its balance sheet as a reaction to the government financing of the additional reserves; they will increase their holdings of the domestic bonds that the government sells (this is effectively the same as present and future tax payments, under Ricardian Equivalence); and at the same time they will increase their issuance of external debt to fund these outgoings and maintain consumption smoothing". If more such private external borrowing is needed, the government then wants to liberalize capital controls. This happens to be the situation with Nigeria like many developing nations; and worst still as a mono-product export economy. More than $90 \%$ of funds going into Nigeria's external reserve are earnings from oil sales in the international market. Conversely, in a more diversified economy, characterized by trade surplus, the government will seek to leverage on its trade advantages by accumulating foreign reserves, reduce or limit external borrowing to capital investment and development of infrastructure, and tighten capital controls by imposing higher capital flow taxes which now aligns with the mercantilist incentive to impose such taxes to 
promote export-led growth accompanied by a weaker real exchange rate.

\section{Empirical Review}

Nwafor (2017), testing a time series data spanning a period between 2004-2015, using the ECM technique finds that external reserve accumulation has no positive significant impact both on Nigeria economic growth as a whole and the foreign exchange rate. The study observes that within the period under review, Nigeria's foreign reserve has been on the decline due, mainly to the global financial crisis.

Akinwumi et al (2006) carried out an empirical analysis of the impact of the foreign external reserve on the economic growth of Nigeria. They regressed exchange rate, monetary policy rate, inflation rate and foreign direct investment as the independent variables and the GDP as the dependent variable as the indices for economic growth. The regression shows a positive relationship between economic growth and foreign direct investment as well as monetary policy rate and a negative relationship between economic growth and exchange rate and inflation rate..

Gong (2012) investigates the economic growth effect of foreign reserve accumulation. The study reveals a positive relationship between reserve accumulation and capital investment in a constrained economy. He argues that the speed of foreign reserve accumulation would slow down with the domestic financial deepening and the development of the domestic financial market. Gong explains that the positive relationship between real economic growth rate and the demand for foreign reserves is the reason holding reserve is a 'catch up' strategy and a second best where the domestic financial market is underdeveloped. In other words, the underdevelopment of the domestic financial market, according to the study is the reason why the demand for reserve accumulation is high in developing countries. Using the Granger causality test, the study observes a two-dimensional significant positive relationship between foreign reserve accumulation and Gross Fixed Capital Formation.

Fakuda and Kon (2010), using a cross country data spanning over 138 countries across Africa, Asia, Europe, Middle east and Southern America investigated the long run macroeconomic impact of accumulation of foreign reserve on developing countries, finds that foreign reserve reduces the cost of liquidity risk. Increase in foreign reserve raises both liquid and total debt while shortening debt maturity in agreement with the a priori expectation that many developing countries have come to recognize increased liquidity as an important form of self-protection against crisis.

\subsection{Bridging the Gap}

This study expands the explanatory variables to include Balance of Payment to capture the country's position in international trade in the period under review and Foreign remittances which in the last decade has become a major foreign exchange earner for developing countries. The time gap between 2010 and 2018 is filled to reflect the current economic realities of the country- a decade that the country has mostly been in recession due to dwindling oil revenues.

\section{Methodology}

The study makes use of secondary data sourced from the United Nations Center for Trade and Development (UNCTAD stat), World Bank and Central Bank of Nigeria (CBN) Publications for various years, Index Mundi Statistical Bulletin and publications from the IMF. The data was tested for stationarity using the Augmented Dickey-Fuller unit root test and long run relationship among the variables was ascertained using the Unrestricted Cointegration Rank test (Trace test). An Error Correction Method and a Granger Causality test were used to estimate the individual and joint relationship between the dependent and explanatory variables.

\subsection{Model Specification}

The model specification adopted in this model was based on the empirical works of Gong (2012), Nwafor (2017) and Akinwumi et al (2006) who in their separate works specified GDP, GDP per capita as the dependent variable but, however differ in the variables that constitute the explanatory variables and time periods. Balance of payment (BOP) and foreign remittances are introduced to our model and the time number of observations extended to the most recent past-2018. In functional form, the model is specified as thus:

GDPC $=\mathrm{F}\{$ EXTRSV, EXTR/GDP, MPR, BOP, EXCHR, FDI, REM $\}$

Where

GDPC

EXTRESV

EXTR/GDP

GDP per capita@2010 constant prices

External Reserve

BOP

External Reserve as a percentage of the GDP

Monetary Policy Rate

EXCHR

FDI

Balance of Payment

Exchange Rate

REM

Foreign Direct Investment

Foreign Remittances from Nigerians working abroad. 
Expressing the functional model in econometric form, we take the logarithm of both sides of the model to linearize the relationship among the variables as;

$\log (G D P C)=\beta_{0}+\beta_{1} \log (E X T R E S)+\beta_{2} \log (E X T R / G D P)+\beta_{3} \log (M P R)+\beta_{4} \log (B O P)+\beta_{5}+\log (E X C H R)$ $+\beta_{6} \log (F D I)+\beta_{7} \log (R E M)+U$

where "U" is the error term.

The study adopts the ex-post-facto research design. The ex-post-facto design deals primarily with secondary data aimed at evaluating the facts and statistical evidence that make up the core of the study without changing or manipulating it. The Autoregressive Distributed Lag (ARDL) model is used to analyze the data gathered for the study. The ARDL analysis consists of three steps:

1) The pre-estimation tests which include the test for stationarity (unit root test) and test for cointegration using the ARDL Bounds test approach.

2) The estimation of the short run and long run coefficients of the model which is carried out using the Auto Regressive Distributed Lag Model (ARDL) test and

3) Diagnostic tests which represents the post-estimation tests and is carried out to test for the robustness of the model estimates. The tests include the coefficient of determination (R-squared) or test for model fitness, autocorrelation, multicollinearity and Granger causality.

4.2 Analysis and Interpretation of Results

Table 1 Unit Root Test

\begin{tabular}{|l|l|l|l|}
\hline Variables & ADF test statistic (Level) & $\begin{array}{l}\text { ADF test statistic } \\
1^{\text {st }} \text { difference }\end{array}$ & Order of integration \\
\hline GDPC & -2.071998 & -3.997595 & $1(1)$ \\
\hline EXTRESV & -1.448025 & -7.273401 & $1(1)$ \\
\hline EXTR/GDP & -2.196691 & -4.953518 & $1(1)$ \\
\hline MPR & -2.502465 & -6.627981 & $1(1)$ \\
\hline BOP & -1.517549 & -6.110156 & $1(1)$ \\
\hline FDI & -1.627196 & -6.429842 & $1(1)$ \\
\hline EXCHR & -0.057045 & -4.581532 & $1(1)$ \\
\hline REM & -2.506935 & -7.413445 & $1(1)$ \\
\hline $5 \%$ critical value -2.976263 & & \\
\hline
\end{tabular}

Source: Extracted from Eviews9 output

The table shows that all the variables are stationary at 1 st difference and therefore, have uniform order of integration. According to Egbulonu and Dim (2018), the determination of the order of integration of the variables establishes the fact that the statistical properties of the variable are constant and do not change over time. We go ahead to test for cointegration using an unrestricted cointegration rank test (Trace test).

Table 2 Unrestricted Cointegration Rank Test (Trace)

\begin{tabular}{|c|c|c|c|c|}
\hline $\begin{array}{l}\text { Hypothesized } \\
\text { No. of CE(s) }\end{array}$ & Eigenvalue & $\begin{array}{c}\text { Trace } \\
\text { Statistic }\end{array}$ & $\begin{array}{c}0.05 \\
\text { Critical Value }\end{array}$ & Prob.** \\
\hline None * & 0.986849 & 320.6882 & 159.5297 & 0.0000 \\
\hline At most $1 *$ & 0.941738 & 203.7440 & 125.6154 & 0.0000 \\
\hline At most $2 *$ & 0.766222 & 126.9880 & 95.75366 & 0.0001 \\
\hline At most $3 *$ & 0.759173 & 87.74671 & 69.81889 & 0.0010 \\
\hline At most $4 *$ & 0.666823 & 49.30743 & 47.85613 & 0.0363 \\
\hline At most 5 & 0.380754 & 19.63227 & 29.79707 & 0.4481 \\
\hline At most 6 & 0.154138 & 6.692468 & 15.49471 & 0.6136 \\
\hline At most 7 & 0.077317 & 2.172677 & 3.841466 & 0.1405 \\
\hline
\end{tabular}

Trace test indicates 5 cointegrating eqn(s) at the 0.05 level

* denotes rejection of the hypothesis at the 0.05 level

**MacKinnon-Haug-Michelis (1999) p-values 
Table 3 Unrestricted Cointegration Rank Test (Maximum Eigenvalue)

\begin{tabular}{ccccc}
\hline \hline $\begin{array}{c}\text { Hypothesized } \\
\text { No. of CE(s) }\end{array}$ & Eigenvalue & $\begin{array}{c}\text { Max-Eigen } \\
\text { Statistic }\end{array}$ & $\begin{array}{c}0.05 \\
\text { Critical Value }\end{array}$ & Prob.** \\
\hline \hline None * & 0.986849 & 116.9442 & 52.36261 & 0.0000 \\
At most 1 & 0.941738 & 76.75596 & 46.23142 & 0.0000 \\
At most 2 & 0.766222 & 39.24129 & 40.07757 & 0.0619 \\
At most 3 & 0.759173 & 38.43928 & 33.87687 & 0.0133 \\
At most 4 & 0.666823 & 29.67516 & 27.58434 & 0.0266 \\
At most 5 & 0.380754 & 12.93980 & 21.13162 & 0.4578 \\
At most 6 & 0.154138 & 4.519790 & 14.26460 & 0.8008 \\
At most 7 & 0.077317 & 2.172677 & 3.841466 & 0.1405 \\
\hline \hline
\end{tabular}

Max-eigenvalue test indicates 2 cointegrating eqn(s) at the 0.05 level

$*$ denotes rejection of the hypothesis at the 0.05 level

**MacKinnon-Haug-Michelis (1999) p-values

Table 4: Regression Result of the Effect of Foreign Reserve Management on Economic Growth

Dependent Variable: D(LNGDPC)

Method: Least Squares

Date: 05/10/19 Time: 05:46

Sample (adjusted): 19942018

Included observations: 25 after adjustments

\begin{tabular}{crcrr}
\hline \hline Variable & Coefficient & Std. Error & t-Statistic & Prob. \\
\hline \hline C & 0.019241 & 0.011646 & 1.652108 & 0.1180 \\
D(LNEXTRESV) & -0.019776 & 0.026594 & -0.743602 & 0.4679 \\
D(EXTGDP) & -0.558611 & 0.091216 & -6.124046 & 0.0096 \\
D(MPR) & 0.002630 & 0.005208 & 0.505049 & 0.6204 \\
D(LNBOP) & 0.016202 & 0.005525 & 2.932422 & 0.0098 \\
D(LNFDI) & 0.060377 & 0.019528 & 3.091817 & 0.0142 \\
D(EXCHR) & 0.000303 & 0.000370 & 0.818384 & 0.4252 \\
D(LNREMIT) & 0.202821 & 0.042575 & 4.763852 & 0.0254 \\
ECM(-1) & -0.340786 & 0.080413 & -4.237947 & 0.0219 \\
\hline \hline R-squared & 0.850049 & Mean dependent var & 0.017710 \\
Adjusted R-squared & 0.775073 & S.D. dependent var & 0.055312 \\
S.E. of regression & 0.050237 & Akaike info criterion & -2.870399 \\
Sum squared resid & 0.040381 & Schwarz criterion & -2.431604 \\
Log likelihood & 44.87999 & Hannan-Quinn criter. & -2.748696 \\
F-statistic & 3.636685 & Durbin-Watson stat & 1.923708 \\
Prob(F-statistic) & 0.011034 & & \\
\hline \hline
\end{tabular}

The regression result on table 5 shows that external reserve accumulation has a negative and significant relationship with the GDP per capita. With a coefficient of -0.019776 shows that a unit increase in Nigeria's external reserve would lead to a decrease in GDP per capita by 0.0197 units. Similarly, there is also a negative but significant relationship between the reserve to GDP ratio and economic growth in Nigeria. The anomalies have been expected because Nigeria economy is highly import based and the terms of trade has been worryingly negative over the years. An increase in the Reserve to GDP ratio by 1 unit would result to a 0.558 unit decrease in economic growth. The result shows that other variables in our model have a positive relationship with the GDP per capita. A unit increase in Monetary Policy Rate, balance of payment, Foreign Direct Investment, exchange rate and foreign remittances leads to a $0.002,0.016,0.06,0.0003$ and 0.20 increases in the GDP per capita respectively. However, the impact of MPR and the exchange rate are found to be insignificant.

The adjusted coefficient of determination of 0.775 or $75 \%$ shows a good fit meaning that $77.5 \%$ of the variation in GDP per capita are explained by the explanatory variables included in our model. The joint test of significance has an F-statistic value of 3.636685 showing a joint positive impact and a probability value of 0.011 meaning that the explanatory variables are jointly significant contributors to economic growth in Nigeria. The 
result further shows that the error correction term (ECM-1) is negative and significant. The ECM-1 estimated at 0.340786 shows the speed of adjustment from the short-run to the long- run equilibrium of the model. This means that about $34 \%$ of the error in our model is corrected in each time period and returns to equilibrium after about three years. The Durbin-Watson value of 1.923708 approximately 2 indicates the absence of autocorrelation in the error term. The intercept of the model is estimated at 0.019241 and is positive meaning that the per capita GDP will grow slightly by 0.019241 units if the explanatory variables in our model are all zero; however, insignificant with a probability value of 0.1180 .

Table 5: Pairwise Granger Causality Tests

Sample: 19902018

Lags: 2

\begin{tabular}{|c|c|c|c|}
\hline Null Hypothesis: & Obs & F-Statistic & Prob. \\
\hline LNEXTRESV does not Granger Cause LNGDPC & \multirow[t]{2}{*}{27} & 2.34919 & 0.1189 \\
\hline LNGDPC does not Granger Cause LNEXTRESV & & 2.07419 & 0.1495 \\
\hline EXTGDP does not Granger Cause LNGDPC & \multirow[t]{2}{*}{27} & 0.83596 & 0.4468 \\
\hline LNGDPC does not Granger Cause EXTGDP & & 0.51166 & 0.6065 \\
\hline MPR does not Granger Cause LNGDPC & \multirow[t]{2}{*}{27} & 0.14408 & 0.8666 \\
\hline LNGDPC does not Granger Cause MPR & & 3.63262 & 0.0433 \\
\hline LNBOP does not Granger Cause LNGDPC & \multirow[t]{2}{*}{27} & 5.98639 & 0.0084 \\
\hline LNGDPC does not Granger Cause LNBOP & & 2.22847 & 0.1314 \\
\hline LNFDI does not Granger Cause LNGDPC & \multirow[t]{2}{*}{27} & 4.82296 & 0.0422 \\
\hline LNGDPC does not Granger Cause LNFDI & & 1.42387 & 0.2621 \\
\hline EXCHR does not Granger Cause LNGDPC & \multirow[t]{2}{*}{27} & 0.36439 & 0.6987 \\
\hline LNGDPC does not Granger Cause EXCHR & & 1.16392 & 0.3308 \\
\hline LNREMIT does not Granger Cause LNGDPC & \multirow[t]{2}{*}{27} & 5.71331 & 0.0010 \\
\hline LNGDPC does not Granger Cause LNREMIT & & 4.94553 & 0.0135 \\
\hline EXTGDP does not Granger Cause LNEXTRESV & \multirow[t]{2}{*}{27} & 0.96225 & 0.3975 \\
\hline LNEXTRESV does not Granger Cause EXTGDP & & 0.49235 & 0.6178 \\
\hline MPR does not Granger Cause LNEXTRESV & \multirow[t]{2}{*}{27} & 3.49338 & 0.0481 \\
\hline LNEXTRESV does not Granger Cause MPR & & 2.36521 & 0.1174 \\
\hline LNBOP does not Granger Cause LNEXTRESV & \multirow[t]{2}{*}{27} & 0.57400 & 0.5715 \\
\hline LNEXTRESV does not Granger Cause LNBOP & & 0.70800 & 0.5035 \\
\hline LNFDI does not Granger Cause LNEXTRESV & \multirow[t]{2}{*}{27} & 1.28363 & 0.2970 \\
\hline LNEXTRESV does not Granger Cause LNFDI & & 2.66407 & 0.0920 \\
\hline EXCHR does not Granger Cause LNEXTRESV & \multirow[t]{2}{*}{27} & 0.46670 & 0.6331 \\
\hline LNEXTRESV does not Granger Cause EXCHR & & 1.19888 & 0.3205 \\
\hline LNREMIT does not Granger Cause LNEXTRESV & \multirow[t]{2}{*}{27} & 8.75374 & 0.0016 \\
\hline LNEXTRESV does not Granger Cause LNREMIT & & 7.86560 & 0.0026 \\
\hline MPR does not Granger Cause EXTGDP & \multirow[t]{2}{*}{27} & 0.15005 & 0.8615 \\
\hline EXTGDP does not Granger Cause MPR & & 0.00746 & 0.9926 \\
\hline LNBOP does not Granger Cause EXTGDP & \multirow[t]{2}{*}{27} & 0.90773 & 0.4180 \\
\hline EXTGDP does not Granger Cause LNBOP & & 1.04520 & 0.3684 \\
\hline LNFDI does not Granger Cause EXTGDP & 27 & 1.74886 & 0.1973 \\
\hline
\end{tabular}


Journal of Economics and Sustainable Development ISSN 2222-1700 (Paper) ISSN 2222-2855 (Online)

\begin{tabular}{|c|c|c|c|}
\hline \multicolumn{2}{|l|}{ EXTGDP does not Granger Cause LNFDI } & \multirow{2}{*}{$\begin{array}{l}1.63081 \\
0.01257\end{array}$} & \multirow{3}{*}{$\begin{array}{l}0.2186 \\
0.9875 \\
0.1982\end{array}$} \\
\hline EXCHR does not Granger Cause EXTGDP & 27 & & \\
\hline EXTGDP does not Granger Cause EXCHR & & 1.74354 & \\
\hline LNREMIT does not Granger Cause EXTGDP & 27 & 0.34324 & 0.7132 \\
\hline EXTGDP does not Granger Cause LNREMIT & & 0.39695 & 0.6771 \\
\hline LNBOP does not Granger Cause MPR & 27 & 0.76950 & 0.4753 \\
\hline MPR does not Granger Cause LNBOP & & 0.81256 & 0.4566 \\
\hline LNFDI does not Granger Cause MPR & 27 & 4.17989 & 0.0289 \\
\hline MPR does not Granger Cause LNFDI & & 1.59784 & 0.2249 \\
\hline EXCHR does not Granger Cause MPR & 27 & 3.50777 & 0.0476 \\
\hline MPR does not Granger Cause EXCHR & & 1.12959 & 0.3412 \\
\hline LNREMIT does not Granger Cause MPR & 27 & 5.91984 & 0.0088 \\
\hline MPR does not Granger Cause LNREMIT & & 15.5309 & 6.E-05 \\
\hline LNFDI does not Granger Cause LNBOP & 27 & 0.43386 & 0.6534 \\
\hline LNBOP does not Granger Cause LNFDI & & 9.27872 & 0.0012 \\
\hline EXCHR does not Granger Cause LNBOP & 27 & 1.88821 & 0.1751 \\
\hline LNBOP does not Granger Cause EXCHR & & 0.62193 & 0.5461 \\
\hline LNREMIT does not Granger Cause LNBOP & 27 & 0.24024 & 0.7885 \\
\hline LNBOP does not Granger Cause LNREMIT & & 0.84305 & 0.4438 \\
\hline EXCHR does not Granger Cause LNFDI & 27 & 0.67452 & 0.5196 \\
\hline LNFDI does not Granger Cause EXCHR & & 0.62856 & 0.5427 \\
\hline LNREMIT does not Granger Cause LNFDI & 27 & 0.13582 & 0.8737 \\
\hline LNFDI does not Granger Cause LNREMIT & & 0.76044 & 0.4794 \\
\hline LNREMIT does not Granger Cause EXCHR & 27 & 1.48889 & 0.2475 \\
\hline EXCHR does not Granger Cause LNREMIT & & 0.95447 & 0.4004 \\
\hline
\end{tabular}

The Granger Causality test shows that a one-dimensional relationship exist between GDP per capita and the external reserve ratio to the GDP, The MPR and the GDP per capita, the Exchange rate and the GDP per capita, the external reserve and the reserve ratio to the GDP, the Exchange rate and external reserve, the exchange rate and the reserve ratio to the GDP, FDI and the BOP, Remittances and the BOP and remittances and foreign direct investment. A two-dimensional relationship exists between MPR and the reserve ratio to the GDP as well as remittances and the reserve ratio. This result shows that the reserve ratio to the GDP is the most dominant variable in our estimation.

\section{Conclusion}

The study investigated the impact of foreign reserve accumulation and the country's reserve management policies on its economic growth for the period 1990 to 2018. Secondary data from the United Nations Center for Trade and Development (UNCTAD), World Bank, IMF and Index Mundi Statistical Bulletin was used in the study. Modeled after the empirical works of Akinwumi et al (2006), Gong (2012) and Nwafor (2017), the ADRL test was used to test for stationarity of data. The OLS result shows that there is an inverse and insignificant relationship between reserve accumulation and the country's economic growth. This conforms to our a priori expectation and the earlier findings of Akinwumi et al (2006).

The role of foreign reserve accumulation in stabilizing the foreign exchange rate and providing a buffer to the Nigerian economy in times of economic and financial crisis has been established in this study. However, the analytical literature shows fluctuations in the country's foreign reserve resulting from mismanagement and depletion of Nigeria's international reserve mostly on domestic consumption and recurrent expenditures at the three levels of the federal structure. By the second quarter of 2019, Nigeria's official exchange rate stands at 
US\$361, raising both liquid and total debt of the country. External debt in Nigeria increased to an all -time high of US\$25,609.63 by the last quarter of 2018, averaging US\$9,626.82 between 2008 and 2018 while its foreign reserve stood at US\$43.6billion.

The implication of this finding is that contrary to contemporary literature, increased foreign reserve has not acted as a stabilizer to Nigeria's foreign exchange rate. This is due, primarily to the fact that Nigeria, as an emerging market has not gotten it right so far in its foreign reserve policies and management. Nigeria's foreign reserves has failed to fulfill its objective of cushioning economic downturn and acting as a buffer to fluctuating exchange rate because it has not been prudently managed to achieve these macroeconomic objectives. This is evident in the country's continuous and persistent plunge into recession in the last decade. The country's external reserve has been depleted over the years; and more so for consumption and recurrent expenditure purposes. The Granger Causality test shows that in the case of Nigeria, there is absolutely no causal relationship, either ways, between foreign reserve accumulation and its exchange rate stability. Rather, the most significant and prominent development finance stream affecting economic growth in the country is foreign workers remittances into the country with coefficient and probability values of 0.2 and 0.02 respectively.

Also, the Reserve to GDP ratio of the country is found to be so low and significantly inversely related to the GDP per capita. Other variables in our model- MPR, BOP, FDI, Remittances are all found to have positive relationship with the MPR and Exchange rate found to be insignificant. The Granger Causality test shows that foreign remittances are a dominant variable in our model.

It is therefore, recommended that:

1. There is an urgent need to readdress the country's foreign reserve management policies to engender growth and stability.

2. Concerted effort should be made to diversify the country's foreign exchange earner as a mono-product exchange economy is bound to face unpredicted swindles like the situation Nigeria has constantly found itself in the international oil market. When there is boom in the international oil market the country tends to accumulate more foreign reserve which quickly depletes with a downturn in the oil market.

3. The monetary authorities should strike a policy balance between savings and consumption; and more so, the proportion of its national income that should go into the foreign reserve and that which should be rightly invested in the economy.

4. The domestic capital market should be strengthened and stabilized. This in agreement with Guillermo (2006) argument that foreign reserve accumulation rather leads to crisis than a solution to it; and that developing countries only tend to accumulate reserve because of the existence of a underdeveloped domestic capital market.

\section{References}

Aizeman,J. and Lee, J. (2005) International Reserves: Precautionary Merchantilist Views. Theory and Evidence Economic Journal 3(6), 1-30.

Akinwumi, A and Adekoye, R (2016): External Reserve Management and its Effect on Economic Growth of Nigeria. International Journal on Business and Finance Management Research.

CBN (2007) Building and Managing External Reserves for Economic Development. The CBN Bullion 31(2).

CBN Statistical Bulletin and Publications (2000, 2005, 2006, 2010, 2016, 2017)

Egbulonu, K.G. and Dim, H. C. (2018) Relationship between Population Growth and Industrial Output in Nigeria; International Journal of Innovation and Research in Education Sciences, Vol.5, Issues 5.

Fakuda, S. and Y. Kon. 2010. Macroeconomic Impact of Foreign Exchange Reserve Accumulation: Theory and International Evidence. ADB Working Paper 197.Tokyo. Asian Development Bank Institute.

Gimi, S.H (2000) Management of Foreign Reserve by Central Bank of Nigeria; Open Air Institutional Repository, ABU Zaria.

Gong, C.(2012) A Growth Perspective of Foreign Reserve Accumulation.

Guillermo,C (2009) Reserve Accumulation and Easy Money Helped to cause the Subprime Crisis: A Conjecture in Search of a Theory; Cambridge MA; MIT Press.

Guillermo ,C (2009) Establishing a Global Lender of Last Resort; Cambridge MA; MIT Press.

Gupita, A and Agarwal, R (2004) How Should Emerging Economies Manage their Foreign Exchange Reserves? Online; https://papers.ssrn.com

IMF (2001) Guidelines for Foreign Reserve Management, International Monetary Fund.

IMF Annual Reports for Various Years

Nwafor, M.C (2017), External Reserve; Panacea for Economic Growth; European Journal of Business Management Vol.9 No.33, 2017

Obadenmi, O.E (2007) Managing Nigeria's Foreign Reserve for Enhanced Macroeconomic Performance; Journal of Business Management Vol.2, No. 1\&2, 2007

Soludo, C. C. (2005) The Challenges of Foreign Exchange Reserve Management in Nigeria: A Keynote Address 
delivered at the UBS Eleventh Annual Reserve Management Seminar, Wolfis, 2-10 June.

United Nations Center for Trade and Statistics Statistical Bulletin, Various Publications

World Trade Organization (2010): International Trade Statistics. 